\title{
Derivatives disclosure in corporate annual reports: bank analysts' perceptions of usefulness
}

\author{
ANNE BEAN* \& HELEN IRVINE \\ School of Accountancy, \\ Queensland University of Technology, \\ Brisbane, QLD Australia
}

We thank the guest editor, Mary Barth, and two anonymous reviewers. We thank Neil Fargher for his helpful comments and suggestions. We are also grateful to Lee Parker, Sue Newberry, Carolyn Cordery, Jonathan Bader, Tracy Artiach and Ann Tarca. An earlier version of this paper was presented at the IASB Research Forum. We would like to thank forum attendees for their feedback and particularly the discussants, Leslie Hodder and Kumar Dasgupta.

*Corresponding author. Email: a.bean@qut.edu.au 


\title{
Derivatives disclosure in corporate annual reports: bank analysts' perceptions of usefulness
}

\begin{abstract}
Responding to mixed evidence on the decision-usefulness of annual report disclosures for derivative financial instruments to capital market participants, and concerns identified by practice, this paper examines usefulness in a direct study of user perceptions. Interviews with analysts from Australia's four major banks reveal essential usefulness, limited by the disclosures' failure to reflect companies' actual use of derivatives throughout the period, and inability of users to understand companies' offbalance sheet risk and risk management practices from information considered generic and boilerplate. The research complements and extends existing archival and survey research and provides new evidence suggesting low cost ways for increasing usefulness. It supports the IASB's disclosure recommendations in its recent Discussion Paper: A Review of the Conceptual Framework for Financial Reporting but, at the same time, highlights that for these proposed measures to be successful in relation to IFRS 7, they may need to address other issues. The research increases knowledge of the informational requirements of lenders, an important class of financial information user, and supports calls from practice for companies to improve their disclosure of material economic risks.
\end{abstract}

Keywords: derivatives; IFRS 7; risk; disclosure; lenders; users 


\section{Introduction}

Despite the prevalence and importance of derivative financial instruments for corporations, and their regular association with financial scandals, companies find it notoriously difficult to summarise risk management practices, end of period balances, and within period performance related to derivatives in a succinct and understandable way. While the International Accounting Standards Board (IASB) and its predecessor have been working on projects related to financial instruments for much of the past 25 years, there has been increasing concern from practice that disclosures are growing in length while decreasing in information value, with poor disclosure quality under IFRS 7 Financial Instruments: Disclosures potentially limiting usefulness to users.

Despite the strong economic basis for derivatives disclosures and concerns identified by practice, academic research in this area has been limited. Some conclusions about the decision-usefulness of disclosures for derivatives can be inferred from archival literature, such as Ryan (2012), who found a less than expected degree of value-relevance or riskrelevance. However, archival research does not usually provide insight into the reasons underlying its results. Other limitations of existing archival research include its emphasis upon the quantitative disclosure requirements of IFRS 7 and focus upon the banking sector. More broadly, this type of research is unable to determine whether financial statements are the source of information used by the market or whether other, undisclosed information might have been more useful. Similarly, recent survey evidence from Johansen and Plenborg (2013), identified high user demand for derivatives disclosure coupled with comparatively low user satisfaction and pointed to a need for more research on why satisfaction is low, or how satisfaction could be increased. This study addresses these areas of limitation.

Drawing upon reports from practice and academic research outlined above, our objective is to explore the usefulness of the information provided about derivatives in the 
annual reports of companies. The IASB defines users in its Conceptual Framework for Financial Reporting (Conceptual Framework) as investors, lenders and other creditors. Primarily, they are the capital market participants who provide finance to an enterprise. To gain insight into the usefulness of disclosures, we interviewed 16 analysts from Australia's four largest banks.

Our first research question asked whether the disclosures for derivatives made under IFRS 7 fulfil their stated purpose, by meeting the decision-making needs of users. To the extent that the analysts found these disclosures less than useful, we asked why. The first research question therefore limited responses to what is currently in the standard. The second research question then asked whether different disclosures might improve usefulness.

Our findings reveal that although the analysts perceived disclosures to be somewhat useful, they criticised them for not providing sufficient insight into companies’ risk and riskmanagement strategies. The first reason identified is that disclosures are often generic and rarely company-specific. The second is that the analysts did not believe companies provide sufficient information about their intra-period activity. Moving beyond the scope of IFRS 7, the analysts were of the opinion that companies should do more to explain and analyse their material economic risk positions.

This paper makes three contributions. First, it complements findings of empirical archival research and recent survey research that indicates preparers should prioritise their financial instrument disclosures. It extends this research by suggesting how preparers might increase user satisfaction without significantly increasing their costs. By providing the analysts’ insights into points of resistance by preparers to the provision of informative disclosures, we make a second contribution, by suggesting ways in which the effectiveness of the IASB's recommendations on disclosures in its Discussion Paper: A Review of the Conceptual Framework for Financial Reporting might be enhanced for IFRS 7. The third 
contribution of the research is to provide new evidence on the use and limitations of these disclosures for credit-side analysts, a key user group about whose informational needs we know relatively little (Armstrong et al. 2010). This also supports calls from practice for companies to provide better information concerning their material economic risks.

The remainder of this paper is organised as follows. Section 2 provides an overview of the requirements of IFRS 7 and a discussion of the literature that informs the research, section 3 sets out the research method and section 4 presents the findings. Section 5 then summarises the findings, highlighting their implications, and identifies the limitations and contributions of the study.

\section{Institutional background and related literature}

In this section, we first provide information on the main disclosure requirements of IFRS 7 that apply to derivatives, as this is what the standard setters have determined users need to know for their economic decision making. Here we also analyse the limited research into the quality of those disclosures in the financial statements of non-banks, as this may have implications for their ultimate usefulness. We then examine the existing literature that directly addresses aspects of the usefulness of the disclosures.

\subsection{IFRS 7 requirements and disclosure quality}

The IASB considers it important that the disclosures for financial instruments, including derivatives, satisfy two broad objectives, both of which are necessary for users to understand these instruments. The first objective is to provide users of financial statements with an understanding of the significance of derivatives for a company's financial position and performance, that is, an explanation of recognised amounts (IASB 2005 para.1(a)). The second, equally important objective, is to provide users with information about companies' exposure to the risks associated with those recognised amounts and also to provide an 
understanding of why management have entered into those risks, and how they are managing them (IASB 2005 para.1(b)). Figure 1 presents a high-level summary of the key requirements of IFRS 7 that apply to derivatives.

\section{INSERT FIGURE 1 HERE}

\subsubsection{Significance of derivatives for financial position and performance}

Requirements applicable to derivatives under the first objective include appropriate levels of aggregation and disaggregation, accounting policies, disclosures for fair value measurement and information on hedging transactions. ${ }^{1}$

IFRS 7 requires companies to group financial instruments into classes that are appropriate to the nature of the information disclosed. While companies determine the level of aggregation they believe is necessary, IFRS 7 provides that, at a minimum, companies not combine information with different measurement characteristics. Companies are also required to disclose their accounting policies such that users may understand the financial statements. Recent Australian research has indicated that not all companies may be complying with even such a basic requirement as providing their accounting policies for derivatives (Birt et al. 2013).

Fair value measurements are classified according to a three level hierarchy determined by the observability of their inputs. ${ }^{2}$ The standard requires the disclosure of

1 In May 2011 the Board relocated the disclosures about fair value measurements from IFRS 7 to IFRS 13 Fair Value Measurement (IASB 2011 paras. 91-99). References in this section are to disclosure requirements now in IFRS 13.

2 Level 1 inputs are quoted prices (unadjusted) in active markets for identical assets or liabilities that the entity can access at the measurement date. Level 2 inputs are inputs other than quoted prices 
measurement methods and assumptions with additional information on the sensitivity of the assumptions used for Level 3 valuations. Clearly, there are increasing opportunities for earnings management as the use of less observable, management originated, inputs increases. Companies have also used undisclosed transfers between levels of the hierarchy to hide losses (Jones 2011, Kothari et al. 2010). Levels 2 and 3 valuations are, however, more commonly found in the financial services sector and are not generally identified as a disclosure quality issue for companies in other sectors.

Hedging is a risk management strategy that involves taking an offsetting position to a risk exposure, such as interest rate risk, foreign exchange risk or commodity-price risk. The purpose of hedge accounting is to reduce measurement mismatches in part caused by our mixed measurement model. IAS 39 Financial Instruments: Recognition and Measurement currently sets very strict hurdles for a transaction to qualify for hedge accounting, quite possibly due to the income smoothing opportunities inherent in hedge accounting, as well as companies’ use of misleading language about hedging to obscure whether derivatives are for the purpose of offsetting risk or taking risk. ${ }^{3}$ A highly anticipated loosening of the restrictions on hedge accounting once IFRS 9: Financial Instruments becomes operative from 2018, will make the hedging disclosures even more critical. IFRS 7 currently requires companies to disclose by type of hedge utilised, a description of the derivatives designated as hedging instruments and the nature, timing and extent of the risks hedged. A large proportion of Australian listed companies engage in hedging activity, with interest rate and foreign

included within Level 1 that are observable for the asset or liability, either directly or indirectly. Level 3 inputs are unobservable inputs for the asset or liability (IASB 2011 paras. 72-90).

3 Companies engage in selective hedging and, in doing so, they are effectively taking a view on whether market changes will benefit or disadvantage them (Bodnar and Gebhardt 1999, Géczy et al. 2007). An example of this is the Australian mining company, Sons of Gwalia Ltd. Prior to its collapse in 2002, none of its directors or management or the highly sophisticated institutional investors who held major positions in the company, seemed to be aware that its hedging strategy was, in fact, highly speculative (Bartholomeusz 2004). 
exchange risk the main risks hedged (Chalmers and Godfrey 2000, Heaney and Winata 2005, Nguyen and Faff 2002). Commodity price hedging is more common in the mining sector (Birt et al. 2013). This profile is consistent with evidence from other countries (Bodnar and Gebhardt 1999). Research conducted by practitioners suggests companies may fail to disclose sufficient specific information about hedges and policies on hedging, potentially limiting users' understanding of how companies manage their risks and their knowledge of whether a well-defined and well-monitored procedure for risk management exists (Papa and Peters 2013).

\subsubsection{Nature and extent of risks and how those risks are managed}

To meet the second objective shown in Figure 1, of providing disclosures that enable an understanding of financial risk and risk management practices, IFRS 7 requires that a company must disclose the financial risks to which it is exposed, which typically include credit risk, liquidity risk and market risk. Companies must describe how each risk arises, how it is measured, management's objectives, policies and processes for managing the risk, and whether there are any changes from the previous period.

Companies are required to disclose summary quantitative information for each risk category, based on information provided internally to management. To the extent that this information is not representative of transactions during the year, a company must provide additional information. IFRS 7 mandates several specific quantitative disclosures over and above the summary requirements. These include information on maximum exposure to credit risk, both with and without the effects of collateral, a maturity analysis for derivative financial liabilities, with contractual maturities where relevant, a description of how liquidity risk is managed and disclosures for market risks. Market risks are key trading exposures and may include interest rate, foreign exchange rate, equity price and commodity price risks. A 
sensitivity analysis is required for each type of market risk to which a company has exposure at the end of the period, showing the effect on profit or loss and equity of a specified change in the market. An alternative to a sensitivity analysis is an analysis of value-at risk (VaR), more commonly used by banks and financial institutions.

Research shows that most quantitative disclosures of off-balance sheet risks tend to be formulaic. With credit risk for example, very few companies appear to provide specific information on concentrations of risk and credit quality of assets that are not past due or impaired (Ernst \& Young 2008, Papa and Peters 2011). For liquidity risk, research finds that the majority of companies do provide required quantitative information on undiscounted cash flows, but fail to consistently provide sufficient detail in narrative disclosures (Ernst \& Young 2008). For market risk, most criticism is directed to companies' lack of disclosure of methods, inputs and assumptions applied in the sensitivity analysis (Ernst \& Young 2008, Papa and Peters 2011). In addition to criticism levelled at the narrative disclosure of methods and assumptions underlying the quantitative disclosures, disclosure of managements' objectives, processes and policies for managing these risks is considered generic and uninformative (Chalmers and Godfrey 2000, Ernst \& Young 2008, Papa and Peters 2011, 2013, Roulstone 1999). This seems an on-going issue, even though in 2010, the IASB added a paragraph to IFRS 7 explaining that qualitative descriptions and explanations are necessary for users to have a full understanding of the quantitative disclosures.

The consensus from various studies on disclosure quality is that the requirements of IFRS 7 are in most cases technically met, but often in ways that are perfunctory and lack transparency. We do not know, however, to what extent this poor disclosure quality affects users. Despite these identified deficiencies, do users still find the information provided under IFRS 7 useful? Research on this topic suggests sophisticated users may be willing to search through an annual report for the information they need (Durocher and Gendron 2010, 
Thinggaard 1996). Consistent with this possibility, Ryan (2012) was of the view that with the right motivation, information provided in the disclosures for derivatives can be successfully analysed. In the next section, we discuss the existing literature that addresses the usefulness of these disclosures.

\subsection{IFRS 7 usefulness literature}

The main body of academic literature relating to IFRS 7 is concerned with the valuerelevance or risk-relevance of particular items contained in disclosures. This archival research predominantly focuses on quantitative disclosures in the financial statements of banks and reports somewhat mixed results. For example, early findings that disclosures of VaR modelling are associated with measures of company value or measures of risk (Jorion 2002, Lim and Tan 2007, Liu et al. 2004) were contradicted in more recent work (Pérignon and Smith 2010). Similarly, research into companies' use of fair values calculated under each of the three levels of fair value suggested some relation between the degree of reliability of the fair value calculation and share price or risk measure, but evidence was also inconsistent (Liao et al. 2010, Riedl and Serafeim 2011, Song et al. 2010). This led Ryan (2012, p. 316) to conclude that ' ... risk disclosures in financial reports are risk-relevant but less so than one would expect given the high-volume of and strong economic bases for those disclosures.'

Another way that academics approach the usefulness construct is by asking users about their views and preferences (Beattie and Pratt 2002). Typically, these direct studies utilise survey questionnaires and interview based methods. Surveys of users are quite sparse and tend to provide more information about investors than lenders (see Beattie and Pratt 2002). However, in one recent study, Johansen and Plenborg (2013) provided evidence on the usefulness of 24 mandatory disclosures, including IFRS 7, by surveying 288 users (private investors, professional investors, sell-side analysts and bank analysts) and 89 companies 
(small, medium, large and state-owned) to obtain their views. They reported that IFRS 7

disclosures are highly demanded by all categories of user, that these are also among the items thought by companies to be most costly to prepare, and that users are comparatively less satisfied with these notes. While these findings clearly point to a need to identify ways to increase satisfaction with disclosures for all users, while considering the cost to preparers, we are not aware of any academic research that asks users for their views on how to improve usefulness. $^{4}$

Given the importance of credit decisions within capital markets, ${ }^{5}$ it is perhaps surprising that relatively little is understood about the ways in which credit-side analysts use specific items of accounting information (Armstrong et al. 2010, Campbell and Slack 2011). Bank analysts' observations are particularly informative as they place a strong emphasis on risk and risk management (Armstrong et al. 2010, Kothari et al. 2010). Further, as the informational requirements of both investors and lenders are similar across many dimensions (Kothari et al. 2010), insights offered by the analysts interviewed in this research extend the existing literature on the usefulness of IFRS 7 disclosures. Acknowledging users' lack of advocacy during the standard setting process (Giner and Arce 2012, Jorissen et al. 2012, 2013, Larson 2007), individual interviews may be more effective in eliciting users’ views (Weetman et al. 1996).

4 There are differing points of view as to what would improve the disclosure of derivatives. Johansen and Plenborg (2013), for example, recommended a reduction in the complexity of the notes required under IFRS 7. Others, in contrast, believed that complex transactions require more rigorous disclosure, not less (e.g. Ryan 2012). Preparers are expected to prefer disclosures that do not have high data processing costs (Elbannan and McKinley 2006). High-cost disclosures include quantitative information that is complex, make use of estimates and/or require new information to be gathered and analysed.

5 Armstrong et al. (2010) estimated that nearly 95\% of all capital raised by companies in 2006 was in the form of debt. 


\section{Research method}

\subsection{The analysts}

This study used semi-structured interviews with 16 risk analysts from Australia’s four largest banks. ${ }^{6}$ Given the banks’ market dominance, we expected that the majority of listed and large private companies that prepare general-purpose financial reports have relationships with them.

The analysts in this study assess risk either incidental to granting credit (credit analyst), or to the provision of risk advisory services for existing clients of the bank (risk advisor). All confirmed that they have clients who use derivatives and, for both categories, the majority are actively involved in recommending derivatives to clients, either to mitigate risk prior to the granting of credit, or as part of advising clients on financial risk management. In either case, the analysts' role is to maximise their bank’s return on capital by providing independent credit analysis on the companies and industries to which the bank has exposure. For this research, both types of analyst confirmed that they use their clients' audited annual reports when making their initial assessments of risk.

The researchers recruited the analysts using industry contacts and the analysts agreed to participate on the understanding that they would not be individually identifiable. Table 1 summarises the characteristics of the analysts interviewed in this study.

INSERT TABLE 1 HERE

6 The Australian banking sector is dominated by four banks that also comprise four of Australia's top five listed companies by market capitalisation: Commonwealth Bank of Australia (A \$145 billion), Westpac Banking Corporation (A \$111 billion), Australia and New Zealand Banking Group (A\$95 billion), and National Australia Bank (A\$89 billion) (ASX 2015). 
To maintain confidentiality, information on the banks or branches associated with individuals is not tabulated. Analyst experience ranged from four to over 30 years, with 11 having greater than ten years' experience. We allocate each analyst a number between 1 and 16 with a prefix: A for analyst or SA for senior analyst, which denotes greater than ten years' experience. As the analysts are from small teams within the banks, there was little sector concentration evident in the sample although their clients exclude other banks.

\subsection{The interviews}

We provided each analyst with a description of the research objectives of the study before their interview. All interviews were conducted either face-to-face or by telephone during January, February and July of 2013 and were recorded. The first researcher conducted all of the interviews, which lasted between 30 and 45 minutes each.

The interview guide is in Appendix 1. We first obtained information about the background of the analysts. The first interview question then addressed the first research question and followed the tradition of evaluating the usefulness of accounting standards against their own stated objectives (Schipper 2007). The focus therefore, was on how, and to what extent, the objectives of the disclosures in both the Conceptual Framework (IASB 2010 para.OB2) and IFRS 7 (IASB 2005 para.1) were met in the annual reports the analysts evaluate. Aligned with the second research question, the second interview question asked the analysts if they had any suggestions for improvement to the requirements of IFRS 7 . We asked analysts to consider their own informational needs, but be constrained by what, in their opinion, could reasonably be included in an annual report.

The interviewer adopted an unobtrusive attitude throughout the interviews, clarifying the requirements of the standard where necessary, but allowing the analysts to respond to the questions in their own terms and to raise and discuss issues that were most important to them. 
The initial interview strategy was adapted when necessary to explore emerging categories (Mason 2002). New categories ceased to emerge after approximately 12 of the 16 interviews, indicating data saturation or informational redundancy, with little to be gained from additional interviews (Lincoln and Guba 1994). This seemed reasonable given the relatively homogeneous characteristics of the analysts and is consistent with evidence that minimum sample sizes for this kind of research fall somewhere between eight (Arksey and Knight 1999) and 12 (Onwuegbuzie and Collins 2007).

\subsection{Data analysis}

The first researcher collected and analysed all of the data. Seven interviews conducted during January and February of 2013 formed the basis of a pro-forma codebook, developed ex post, based upon the responses of the analysts. There was no a priori theorising. Coding was systematic with a code initially created for each observation. Through the identification of similar or related comments, codes were refined and categories and sub-categories emerged. This preliminary data, grouped by category, was then displayed on a spread-sheet (Miles and Huberman 1994), which aided the identification of relationships between the categories, leading to a return to the data and the codes in an iterative process. In establishing these relationships, a search for rival explanations and negative cases was undertaken (Patton 2002). The first researcher transcribed the first seven interviews and a professional transcription service transcribed the second tranche of nine interviews. At this time, the first researcher uploaded the pro-forma codebook and all interview transcripts into Nvivo, a software program designed to help manage and analyse non-numerical, unstructured data. She repeated the manual process described above using the software, which served to improve reliability of the coding. The second researcher checked and verified the data, 
coding and conclusions of the analysis. ${ }^{7}$

\section{Findings}

The first interview question defines the decision-usefulness of the disclosures in accordance with IFRS 7, and therefore parallels the two high level objectives of IFRS 7 described in section 2.1. Analysts were asked 'to what extent do the disclosures allow you to evaluate the significance of derivatives for an entity's financial position and performance, understand their risk, and understand an entity’s practices and processes for managing that risk.'

The analysts saw the disclosures produced in accordance with IFRS 7 as a useful starting point and all confirmed that they do actually read their clients' annual reports. At a minimum, the accounts show open positions at year-end, which nine of the analysts believed provides some idea of the significance of derivatives to a company's operations, consistent with the first objective of IFRS 7. These analysts considered this ability to identify the significance of derivatives for financial position and performance to be important, even subject to the limitations later identified. For example, it allows them to identify whether the derivatives a company holds at year-end seem appropriate for its business model. It enables them to look for red flags, that is, 'things that don’t stack up.' One senior analyst (SA14) observed that sometimes there is sufficient information for preliminary benchmarking of a client against its industry peers and competitors.

The majority of analysts identified two limitations affecting the usefulness of the disclosures. Both relate to the second objective of IFRS 7, which states that users should be able to understand an entity's risk and their practices and processes for managing that risk.

7 Yin (2009) recommended the creation of a case database and the clear provision of a chain of evidence, which others sometimes refer to as an audit trail (Shenton 2004). The chain of evidence provides assurance that the evidence originally collected connects with what is in the final report. In the opposite direction, it provides assurance that no original evidence has been lost through carelessness or bias. We follow Yin's (2009) recommendation. 
We discuss these issues in the next two sections. Section 4.1 addresses the issue that the analysts spent the most time discussing: the generic nature of the disclosures about risk and risk management usually provided by companies. We explore the second limitation in section 4.2: analysts’ identification of a potentially misleading end-of-year focus in many annual reports. Section 4.3 presents the analysts' opinions on why companies may struggle with these disclosures.

\subsection{The disclosures are generic}

The majority of the analysts (14) were dissatisfied with the superficial or generic nature of disclosures.

Part of the reason why we were interested in having this interview with you was because we actually do find it quite difficult to work out what the risks are for companies, just purely from public disclosures. (SA13)

...the financial statements in general, are a very poor reflection of the risk management practices that are actually being used. (A10)

I don't think they're particularly useful because of them being quite the same across different businesses. (A9)

Analysts emphasised that reading about companies’ policies and processes for identifying, measuring, and managing, risks provides them with some idea of management's understanding and sophistication in this area, which is important when dealing with derivatives. Further, analysts considered narrative disclosures essential to their ability to understand the quantitative information provided about risk exposures.

In terms of quantitative risk disclosures, six analysts noted that for sensitivity analyses of market risk most companies use a $1 \%, 5 \%$ or $10 \%$ change in the risk variable irrespective 
of how realistic these changes might be. Of these, two said they still found this disclosure useful and four did not.

I've seen $10 \%$ and I think I've seen 5\% but they're generally - look it's an exercise for them, they need to tick a box. (A2)

These comments by analysts about generic disclosures are consistent with concern from practice that disclosures generally are growing in length while decreasing in informativeness (FRC 2009, 2011, Hoogervorst 2013, IASB 2008a, 2008b, KPMG 2011). The analysts' comments also support the IASB's disclosure recommendations in the Discussion Paper: $A$ Review of the Conceptual Framework for Financial Reporting (IASB 2013b). In the discussion paper, there is a call for preparers to see financial statements as a form of communication guided by standards, as opposed to a 'mechanism whose sole purpose is compliance with specific requirements of Standards’(IASB 2013b para. 7.49).

\subsection{Misleading end of period focus}

A second limitation to the usefulness of the disclosures identified by nine of the analysts was a perception that companies tend not to properly disclose their intra-period activity. The analysts believed that if or when activity during the year differs from year-end positions, companies in many cases either ignore these differences or else address them with generic narrative. These nine analysts, more than half of the sample, said that they had direct knowledge of companies doing this.

For all you know, the day before, they've reduced their positions dramatically for their end of year reporting and then the following day, put them all back on again - and this absolutely happens. Companies manage their derivatives. (SA6)

$\ldots$ if I looked at any type of public company, probably $80 \%$ of the time I'd presume they only use very vanilla derivatives, but the reality is ... [the] non- 
vanilla stuff it's not there at year end, and that's common practice in companies; to use those other instruments in between period-ends. (SA11)

Some analysts linked this issue to the strict definitions of hedges in IAS 39 that may not match companies' economic reality, explaining that they have observed clients closing out positions before year-end to avoid disadvantageous accounting treatments.

I think that behaviour is driven more by the restrictions in the current hedge accounting standards. Meaning that some businesses - no, not just some - many businesses that hedge look to the accounting standards to determine what sort of hedging they can use ... Those tools might not get them the economic outcomes they want so they utilise different derivatives throughout the year to provide them with the exposure they really want. (A9)

... a lot of our clients are happy to use purchase options ... often this is considered the best form of risk management because you are protected [from losses greater than the premium paid] with only gain on the upside. But a lot of them will not have the options unexpired at year end. They clearly tell us we don't want this at year end. So they would transact options during the year and a couple of days before year end ... close out everything. (SA12)

The high-level aim of the new hedge accounting model in IFRS 9, is to better align companies’ risk management practices with accounting outcomes, which may alleviate this problem. However, while it is possible that companies will find the new model more responsive to their needs, onerous hedging rules were not the sole reason given for the end of year focus of the accounts. Also mentioned by analysts were active decisions by audited companies to avoid disclosure.

There's also strategy ... [for example, using] the benefits of optionality to enhance a rate and then they close that out to ensure they don't carry any of these structured products over the year end. (SA12) 
We do a bit of work with a very innovative treasury in the manufacturing sector and they're very aggressive. They do a lot of things like selling optionality ... to boost their hedge rates and all that. They've got a policy around it, so they're not just [being] all very gung-ho about it. It's all within policy. But when you contrast that with what's disclosed in the financial statements, it's a far cry from that. So it's very innocuous in the financial statements, but in practice, and in reality, they're progressive, very aggressive. (A10)

If these perceptions accurately reflect practice, this non-disclosure of intra-period activity is concerning, whatever the reason. IFRS 7 specifically states that users must be able to evaluate 'the nature and extent of risks arising from financial instruments to which the entity is exposed during the period and at the end of the reporting period' (IASB 2005 para.1(b) emphasis added). Prior research suggests that non-bank companies' use of derivatives for risk management is affected by the accounting treatment (Bodnar and Gebhardt 1999, Glaum and Klöcker 2011, Lins et al. 2011), and year-end window dressing for various reasons has been observed with banks (Allen and Saunders 1992, Jones 2011, Owens and Wu 2014). However, we are not aware of any other research that indicates non-banks may be using derivatives either for risk management or for speculation intra-period without disclosing them.

When asked how they think companies avoid making these required disclosures, most analysts blamed the use of generic descriptions in the narrative.

They will just cover that by saying 'we sometimes transact FX options.' (SA11)

That's what those one liners around 'the company has used FX forwards and options to manage such and such risk, no such derivatives are outstanding at year end', that's where that comes from. But literally, those are one-liners in my experience. (SA13)

Again, if these comments by analysts accurately portray practice, effectively avoiding disclosure by the use of broad-brush statements does not seem to be in the spirit of the 
accounting standard. Essentially, by not making these activities clear, companies are either overstating or understating their risk. If companies are not disclosing that they are economically hedging a portion of their budgeted foreign currency revenue, for example, they are implicitly overstating their exposure to foreign exchange risk. As one analyst pointed out, it would not be a particularly onerous requirement to ask companies to disclose information such as notional amounts bought and sold by type of instrument during the year, and would not require any change to the accounting standard. (SA11)

\subsection{Reasons for uninformative disclosures}

Many of the analysts offered opinions, based upon their interactions with clients, as to why they believe companies seem to have so much difficulty with the disclosures required by IFRS 7. Most commonly mentioned was companies’ over-use of audit firms’ example financial statements, which they variously linked to companies' belief that risk information is commercially sensitive, that companies may lack formal risk management policies meaning they have nothing specific to disclose, and poor understanding of derivatives and risk by auditors and company accountants.

\subsubsection{Over-use of audit firms example financial statements}

Eight analysts suggested that audit firms allow companies to use boilerplate statements and mentioned companies copying Big 4 example financial statements in this context.

The accounting firms let companies get away with being so generic ... I can tell you word for word what's in their disclosures ... and it'll be something pulled out of the standard financial accounts. (SA11)

It's almost like there's a cut and paste club amongst a lot of the financial reporting fraternity [laughs] that say, yes these are the words that we can use to satisfy the requirements. (SA15) 
That 'financial reports provide evidence of auditors not being willing to exercise professional judgment' is an issue previously raised with the IASB (IASB 2013a, p. 7). In turn, the IASB has suggested risk aversion may explain a compliance focused approach by auditors and preparers (Hoogervorst 2013).

\subsubsection{Information may be considered commercially sensitive}

Nine analysts talked about the potential commercial sensitivity of risk information. Of these, eight believed that companies restrict information on risk management in the notes if or when they consider it commercially sensitive.

...but I'm sure there's a degree of commercial practice in so far as you want to protect what your strategies might be. (A10)

...most companies we deal with, they'll just keep to the standard and, I mean, they'll keep the full proper disclosure, but some of these matters might be commercially sensitive as well as, uncompetitive, so it's... (SA7)

However, there is an alternative view that at the high level such information could conceivably be included in an annual report, the information is not likely to be proprietary (Lee 2012, Ryan 2008). In several cases where the interviewer suggested this possibility, the analysts retreated from their initial sympathy with this viewpoint, agreeing that:

I think there is, there's definitely a gap there that needs to be filled in, and I think it is possible to do that without giving away internal intellectual property. (SA5)

\subsubsection{Companies lack formal risk management policies}

Six analysts observed that they do not believe that many companies actually have detailed risk management policies and offered this as a possible reason for over reliance upon generic wording from audit firms’ example financial statements. 
One thing that continues to surprise us is the number of companies whose boards actually don't have a formal treasury policy - and I’d say it’s increasing. (SA14)

We can't discount the situation where clients actually don't have any policies in place. You'd be very surprised ... So the ambiguous disclosures you get in the financial statements may actually be accurate! (A10)

This is consistent with previous evidence that, of Australia's top 100 companies, the top 50 are more likely to have properly documented policies and internal controls over derivatives than the bottom 50 (Matolcsy and Petty 2001), potentially leaving any number of smaller listed companies without appropriate documentation of their strategies for risk management.

\subsubsection{Accountants and auditors don't understand derivatives}

Four analysts suggested that the use of generic templates, perhaps based upon standard financial statements, occurs because members of audit teams do not understand derivatives and risk, any more than the corporate accountants who prepare the notes.

I must admit I see ... [our] amateur clients sitting with the auditor, and they seem to be these very young, fresh-faced people who are not quite sure what sort of questions they're asking. [I don't know] whether they're just ... ticking boxes. (SA15)

Concerning, but not necessarily surprising, is the possibility that accountants and auditors are out of their depth as derivatives increase in complexity. This has been raised before in the literature (Le Guyader 2013, Sikka 2009).

The second interview question asked whether the analysts have any views on how they would like to see the disclosures improved beyond the current requirements of IFRS 7. In most cases, analysts referred back to matters already discussed, such as wanting better quality disclosures that are more company specific and informative. However, one new issue 
did stand out: analysts’ inability to identify overall or economic risk from the current disclosures.

\subsection{Disclosure of material economic risks and risk management}

Seven of the analysts believe that IFRS 7 should require disclosures that provide a better view of companies' material risk and risk management activities. As outlined in section 2.1, IFRS 7 requires disclosure of risk arising from financial instruments and separate disclosures on hedging arrangements that qualify for hedge accounting treatment. What IFRS 7 does not require, however, is the disclosure of economic hedges or natural hedges. When a company enters into a transaction using derivatives for the purpose of risk management that does not qualify under the strict rules for hedge accounting, this may be an economic hedge. Any such derivative would be classified as held for trading and it can be very difficult to identify its purpose as an economic hedge (Ernst \& Young 2008). A natural hedge arises when a company in the ordinary course of its business has positions that offset each other. A simple example might be foreign currency bank accounts naturally offsetting the currency risk of foreign currency accounts payable. Also excluded because they are outside of the scope of IAS 39 are own contracts, forecasted transactions and firm commitments, as well as net assets and profits and losses of foreign subsidiaries (Ernst \& Young 2008). There is consequently no requirement for a company to disclose the extent of its risk and risk management activities in any economic sense. Under current IFRS risk, and especially hedging, are primarily accounting constructs.

Three of the analysts used foreign exchange risk as an example of a risk that they are interested in because it is often material for Australian companies.

From our point of view we have to talk to the customer to get a full understanding of what FX exposures they've actually got - that company may have payables and receivables, [which] equals [a] natural hedge, but it certainly won't be $100 \%$ 
offset. There'll still be some FX exposure and I don't believe when I look at the notes I can tell what that is. Then they've got other currencies and cross currencies, and then AUD as functional currency ... looking at this very small note that talks about some FX hedging or FX swaps that are currently entered into at the balance date; that doesn't give you a perspective of the year. It gives you no perspective of what the FX risk is on an on-going basis without going to the customer. Gives no idea what ... they're doing to protect against volatility during the year. (SA14)

Others made the point that risk is not just about derivatives and financial instruments that are within the scope of IAS 39 and IFRS 7:

A transport company for example, uses a lot of diesel, so they're exposed to diesel price risk, but what if, in their transport contracts with customers, they pass that diesel price risk through contractually. They've effectively hedged that risk and that might be - that might turn up in the notes to the accounts. It might not. (SA16)

What is particularly interesting about these comments, which were unprompted by the interviewer, is how closely they align with views expressed in research conducted by practice. For example, Ernst \& Young (2008) noted that reconciling market risk disclosures with economic risk is difficult due to transactions falling outside the scope of IFRS 7. The CFA Institute in the UK (Papa and Peters 2011, p. 2) recommended that companies 'should provide an executive summary that distils key information on entity-wide risk exposures and effectiveness of risk management practices across different risk types.' Standard setters must use judgement to strike a balance between sufficient levels of mandatory disclosure and imposition of costs. However, the adoption of IFRS 9, with its expanded hedging model and hedging disclosures based upon type of risk rather than type of hedge, perhaps provides an opportunity for companies to reflect on how they might link the disclosure of their hedging activities to their disclosure of financial risks. 


\section{Discussion and conclusions}

The first research question sought perceptions from sophisticated users of financial statements about the usefulness of the disclosures for derivatives. The analysts interviewed indicated that, while useful to some extent, the disclosures tend to be prepared in a way that is generic and uninformative and focus upon year-end positions to the detriment of any real understanding of risk and risk management practices. The analysts' responses to this question suggest that preparers may increase user satisfaction by making their existing disclosures less generic and more company specific. Given that concerns about the high cost of financial instruments disclosures have been identified (Johansen and Plenborg 2013), our research may serve to alleviate those concerns. Our interviews with analysts revealed little demand for nonbanks to increase quantitative disclosure or undertake more advanced modelling that would be complex and therefore costly.

The perception that companies tend to disclose only end of year positions that may be unrepresentative of transactions during the year was the second key issue identified in response to the first research question. This problem was highlighted as one aspect in the collapse of Lehmann Bros and has been well documented for samples of banks (Allen and Saunders 1992, Owens and $\mathrm{Wu}$ 2014). To the extent that companies do hold different positions during the year than at year-end, the inclusion of notional amounts by type of instrument traded may be a partial solution, and for most companies it would be relatively simple to provide this information. ${ }^{8}$ It would also not require any change to IFRS 7.

8 Another alternative sometimes suggested is for companies to report average positions during the period, however, not all companies currently revalue their positions regularly (Matolcsy and Petty 2001) or update their hedge accounting, which might increase the cost of this approach. 
In order to encourage companies to improve the informativeness of their disclosures, it is helpful to identify possible sources of resistance. Identifying an over reliance upon the example financial statements promulgated by audit firms, some analysts suggested that resistance to more informative disclosure might revolve around perceptions that information is commercially sensitive. The responses of the analysts when challenged on this viewpoint indicate potential benefits from educating preparers. Some analysts claimed that they observe their clients using derivatives without clearly documented strategies, limits and internal controls. This would presumably have an effect upon a company's ability to explain its risk management strategy in the footnotes and, if widespread, could have important implications for company directors and auditors (e.g. Drummond 2005). Some analysts also believed a lack of understanding of derivatives and risk by both auditors and company accountants is a reason for companies to favour generic disclosures that are overly reliant upon audit firms' example financial statements. The audit of derivatives frequently focuses on review procedures (Gniewosz et al. 2001), which are likely to be ineffective if not conducted by an auditor with the relevant knowledge of the area.

The response by the analysts in this study to the second research question provides support to research conducted by practice (Ernst \& Young 2008, Papa and Peters 2011, 2013) and indicates that usefulness can be improved if companies disclose their material risks in a more integrated way than is currently required under IFRS 7. While indicating a need for further research in this area, our findings reinforce the conclusion of Johansen and Plenborg (2013) that companies should not underestimate user demand for this information.

This research also provides insights into how banks use these disclosures. Most notable is the extent to which the analysts seem to focus upon qualitative disclosures. They use them to draw preliminary conclusions about the competence and sophistication of managements' risk strategies. Analysts made it clear that the numbers mean little without an 
information ecosystem to support them (Lee 2012). Within financial risk, analysts focused on particular material risk categories, such as foreign currency, and identified the need for disclosures that provide insight into the overall risk in these areas. We also note that analysts used disclosures to identify 'red flags', that is, excessive or insufficient hedging, instruments that are inconsistent with other companies in the industry, or speculation.

This study should be interpreted in light of its limitations. First, the evidence comprises interviews with 16 credit-side analysts across four major Australian banks. While these analysts are highly experienced in both derivatives and risk, their responses reflect their opinions and beliefs and may not generalise to all bank analysts or all users. However, given the experience of the analysts and the difficulty in gaining access to them, their views do expand our knowledge and highlight issues worthy of further research. Second, while we framed the research questions using the IASB's own construction of usefulness, the analysts were encouraged to discuss their own views within this framework. Although this approach benefits from its ability to identify what is most important to the people interviewed, rather than what is most important to the researcher, and while there was significant commonality across the analysts' views, not all analysts discussed or identified the same things, which reduces reliability. Third, the analysts' opinions regarding the reasons for companies' reliance upon generic disclosures, while based on direct experience with their clients, does involve elements of speculation and should be interpreted accordingly.

This research makes three main contributions. First, it complements empirical archival research and survey research confirming that preparers should prioritise these disclosures. It then extends this research with new evidence that suggests simple and cost effective ways for enhancing usefulness. Second, by providing insight into resistance by preparers to making disclosures more informative, it supports the IASB's disclosure recommendations in its Discussion Paper: A Review of the Conceptual Framework for 
Financial Reporting. At the same time, it highlights that for these proposed measures to be successful in relation to IFRS 7, the IASB may need to address other related issues. Finally, it provides new evidence on the use and limitations of the disclosures for credit-side analysts, a key user group about whose informational needs we know relatively little, supporting calls from practice for companies to increase their disclosure of material economic risks. Our research contributes to the on-going debate about disclosure and points to ideas for future research. 


\section{References}

Allen, L., \& Saunders, A. (1992). Bank window dressing: theory and evidence. Journal of Banking \& Finance, 16(3), 585-623.

Arksey, H., \& Knight, P. (1999). Interviewing for Social Scientists: An Introductory Resource With Examples: Sage Publications Ltd.

Armstrong, C. S., Guay, W. R., \& Weber, J. P. (2010). The role of information and financial reporting in corporate governance and debt contracting. Journal of Accounting and Economics, 50(2), 179-234.

ASX (2015). ASX 200 list, Australian Stock Exchange. Retrieved 1 June 2015 from http://www.asx200list.com/

Bartholomeusz, S. (2004, 4 September). Sons of Gwalia's gold hedging had big holes, Sydney Morning Herald. Retrieved from http://www.smh.com.au/articles/2004/09/03/1093939143587.html\#

Beattie, V., \& Pratt, K. (2002). Voluntary Annual Report Disclosures: What Users Want: Institute of Chartered Accountants of Scotland.

Birt, J., Rankin, M., \& Song, C. L. (2013). Derivatives use and financial instrument disclosure in the extractives industry. Accounting \& Finance, 53(1), 55-83.

Bodnar, G. M., \& Gebhardt, G. (1999). Derivatives usage in risk management by US and German non-financial firms: a comparative survey. Journal of International Financial Management \& Accounting, 10(3), 153-187.

Campbell, D., \& Slack, R. (2011). Environmental disclosure and environmental risk: sceptical attitudes of UK sell-side bank analysts. British Accounting Review, 43(1), 54-64.

Chalmers, K. G., \& Godfrey, J. M. (2000). Practice versus prescription in the disclosure and recognition of derivatives. Australian Accounting Review, 10(21), 40-50.

Drummond, M. (2005, 22 August). How Sons of Lalor built, then sank, Sons of Gwalia, Sydney Morning Herald. Retrieved from http://www.smh.com.au/news/business/howsons-of-lalor-built-then-sank-sons-of-gwalia/2005/08/21/1124562748347.html

Durocher, S., \& Gendron, Y. (2010). IFRS: On the docility of sophisticated users in preserving the ideal of comparability. European Accounting Review, 20(2), 233-262.

Elbannan, M., \& McKinley, W. (2006). A theory of the corporate decision to resist FASB standards: an organization theory perspective. Accounting, Organizations and Society, 31(7), 601-622.

Ernst \& Young. (2008). Observations on the implementation of IFRS 7 in corporate entities. United Kingdom: EYGM Limited.

FRC. (2009). Louder than words: principles and actions for making corporate reports less complex and more relevant. London: Financial Reporting Council. 
FRC. (2011). Cutting clutter: combating clutter in annual reports. London: Financial Reporting Council.

Géczy, C. C., Minton, B. A., \& Schrand, C. M. (2007). Taking a view: corporate speculation, governance, and compensation. The Journal of Finance, 62(5), 2405-2443.

Giner, B., \& Arce, M. (2012). Lobbying on accounting standards: evidence from IFRS 2 on share-based payments. European Accounting Review, 21(4), 655-691.

Glaum, M., \& Klöcker, A. (2011). Hedge accounting and its influence on financial hedging: when the tail wags the dog. Accounting and Business Research, 41(5), 459-489.

Gniewosz, G., Fargher, N., \& Simnett, R. (2001). Auditors' assessment of hedge effectiveness. International Journal of Auditing, 5(1), 3-19.

Heaney, R., \& Winata, H. (2005). Use of derivatives by Australian companies. Pacific-Basin Finance Journal, 13(4), 411-430.

Hoogervorst, H. (2013). Breaking the boilerplate. Paper presented at the IFRS Conference, Amsterdam.

IASB. (2005). IFRS 7 Financial Instruments: Disclosures. London: International Accounting Standards Board.

IASB. (2008a). Board Discussion and Papers: IASB/FASB Meeting: 24 March. London: International Accounting Standards Board.

IASB. (2008b). Discussion Paper: Reducing Complexity in Reporting Financial Instruments. London: IASB.

IASB. (2010). The Conceptual Framework for Financial Reporting. London: International Accounting Standards Board.

IASB. (2011). IFRS 13 Fair Value Measurement. London: International Accounting Standards Board.

IASB. (2013a). Discussion Forum - Financial Reporting Disclosure Feedback Statement. London: International Accounting Standards Board.

IASB. (2013b). Discussion Paper: A Review of the Conceptual Framework for Financial Reporting. London: International Accounting Standards Board.

Johansen, T. R., \& Plenborg, T. (2013). Prioritising disclosures in the annual report. Accounting and Business Research, 43(6), 605-635.

Jones, M. (2011). Creative Accounting, Fraud and International Accounting Scandals. Chichester, UK: John Wiley \& Sons.

Jorion, P. (2002). How informative are value-at-risk disclosures? Accounting Review, 77(4), 911-931. 
Jorissen, A., Lybaert, N., Orens, R., \& Van Der Tas, L. (2012). Formal participation in the IASB's due process of standard setting: a multi-issue/multi-period analysis. European Accounting Review, 21(4), 693-729.

Jorissen, A., Lybaert, N., Orens, R., \& van der Tas, L. (2013). A geographic analysis of constituents' formal participation in the process of international accounting standard setting: do we have a level playing field? Journal of Accounting and Public Policy, 32(4), 237-270.

Kothari, S. P., Ramanna, K., \& Skinner, D. J. (2010). Implications for GAAP from an analysis of positive research in accounting. Journal of Accounting and Economics, 50(2-3), 246-286.

KPMG. (2011). Disclosure Overload and Complexity: Hidden in Plain Sight. Delaware: KPMG LLP.

Larson, R. K. (2007). Constituent participation and the IASB's International Financial Reporting Interpretations Committee. Accounting in Europe, 4(2), 207-254.

Le Guyader, L. P. (2013). Can accountants understand derivatives? Journal of Corporate Accounting \& Finance, 24(6), 49-54.

Lee, P. (2012). Discussion of 'Risk reporting quality: implications of academic research for financial reporting policy’ by Stephen G. Ryan (2012). Accounting and Business Research, 42(3), 325-327.

Liao, L., Kang, H. H. J., Morris, R., \& Tang, Q. (2010). Information asymmetry of fair value accounting and loan loss provisions during the global financial crisis. Available at SSRN 1569076.

Lim, C. Y., \& Tan, P. M.-S. (2007). Value relevance of value-at-risk disclosure. Review of Quantitative Finance and Accounting, 29(4), 353-353.

Lincoln, Y. S., \& Guba, E. G. (1994). Naturalistic Inquiry (2nd ed.). Newbury Park, C.A.: Sage Publications, Inc.

Lins, K. V., Servaes, H., \& Tamayo, A. (2011). Does fair value reporting affect risk management? International survey evidence. Financial Management, 40(3), 525-551.

Liu, C. C., Ryan, S. G., \& Tan, H. (2004). How banks' value-at-risk disclosures predict their total and priced risk: effects of bank technical sophistication and learning over time. Review of Accounting Studies, 9(2), 265-294.

Mason, J. (2002). Qualitative Researching. Thousand Oaks, CA: Sage.

Matolcsy, Z. P., \& Petty, J. D. (2001). Internal reporting of derivatives: some Australian evidence. Australian Accounting Review, 11(23), 26-33.

Miles, M. B., \& Huberman, A. M. (1994). Qualitative Data Analysis (2nd ed.). Thousand Oaks, CA: Sage Publications Ltd. 
Nguyen, H., \& Faff, R. (2002). On the determinants of derivative usage by Australian companies. Australian Journal of Management, 27(1), 1-24.

Onwuegbuzie, A. J., \& Collins, K. M. T. (2007). A typology of mixed methods sampling designs in social science research. The Qualitative Report, 12(2), 281-316.

Owens, E. L., \& Wu, J. S. (2014). Quarter-end repo borrowing dynamics and bank risk opacity. Simon School Working Paper No. FR 11-15. Available at SSRN:. Retrieved from http://ssrn.com/abstract=1811110

Papa, V., \& Peters, S. (2011). User Perspective on Financial Instruments Risk Disclosures Under International Financial Reporting Standards. London: CFA Institute.

Papa, V., \& Peters, S. (2013). User Perspective on Financial Instruments Risk Disclosures Under IFRS - Derivatives and Hedging Activities Disclosures. London: CFA Institute.

Patton, M. Q. (2002). Qualitative Research and Evaluation Methods. Thousand Oaks, CA: Sage.

Pérignon, C., \& Smith, D. R. (2010). The level and quality of value-at-risk disclosure by commercial banks. Journal of Banking \& Finance, 34(2), 362-377.

Riedl, E. J., \& Serafeim, G. (2011). Information risk and fair values: an examination of equity betas. Journal of Accounting Research, 49(4), 1083-1122.

Roulstone, D. T. (1999). Effect of SEC Financial Reporting Release no. 48 on derivative and market risk disclosures. Accounting Horizons, 13(4), 343-363.

Ryan, S. G. (2008). Accounting in and for the subprime crisis. Accounting Review, 83(6), 1605-1638.

Ryan, S. G. (2012). Risk reporting quality: Implications of academic research for financial reporting policy. Accounting and Business Research, 42(3), 295-324.

Schipper, K. (2007). Required disclosures in financial reports. Accounting Review, 82(2), 301-326.

Shenton, A. K. (2004). Strategies for ensuring trustworthiness in qualitative research projects. Education for Information, 22(2), 63-76.

Sikka, P. (2009). Financial crisis and the silence of the auditors. Accounting, Organizations and Society, 34(6), 868-873.

Song, C. J., Thomas, W. B., \& Yi, H. (2010). Value relevance of FAS no. 157 fair value hierarchy information and the impact of corporate governance mechanisms. Accounting Review, 85(4), 1375-1410.

Thinggaard, F. (1996). Mark-to-market accounting, hedge accounting or historical cost accounting for derivative financial instruments? A survey of financial analysts in Denmark. European Accounting Review, 5(1), 57-75. 
Weetman, P., Davie, E. S., \& Collins, W. (1996). Lobbying on accounting issues: preparer/user imbalance in the case of the operating and financial review. Accounting, Auditing and Accountability, 9(1), 59-76.

Yin, R. K. (2009). Case Study Research: Design and Methods. Thousand Oaks, CA: Sage Publications Ltd. 


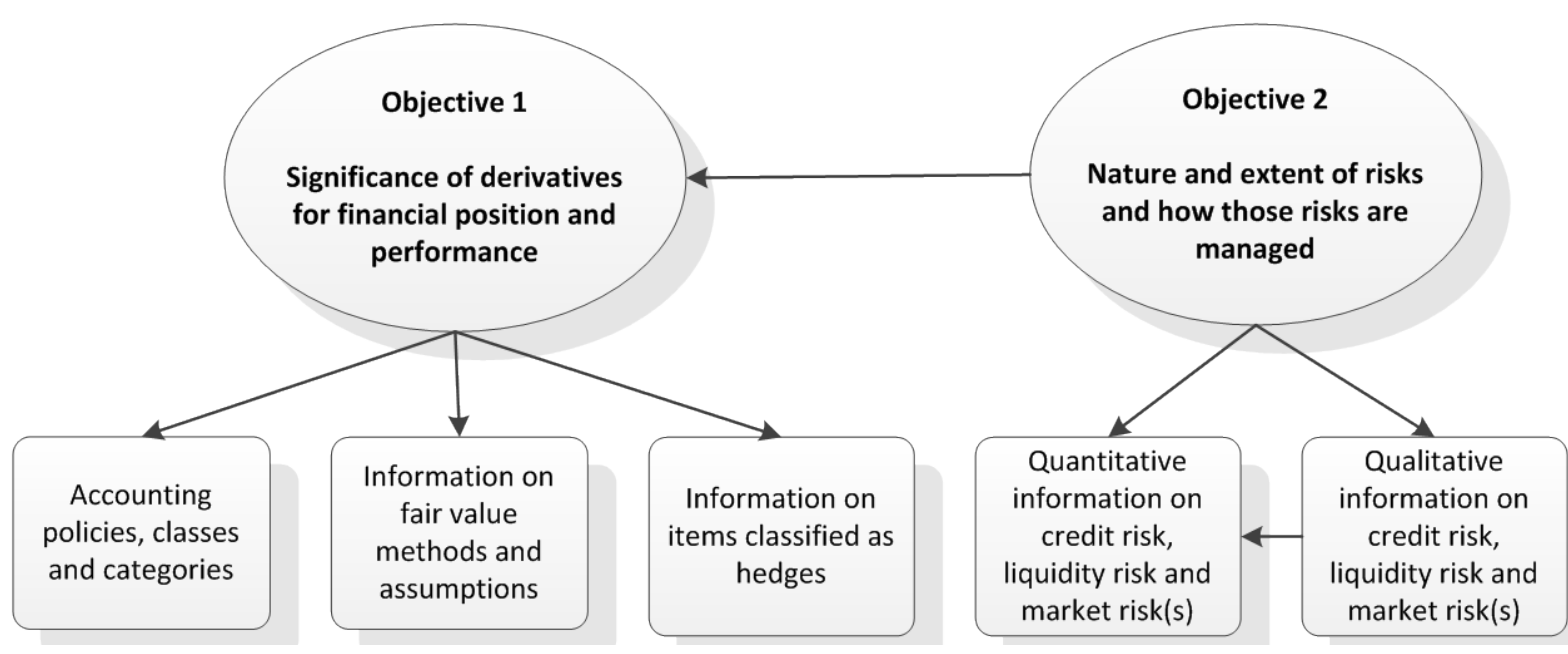

Figure 1 The objectives and disclosure requirements of IFRS 7 most relevant to derivative financial instruments

Table $1 \quad$ Participant profiles

\begin{tabular}{llll}
\hline $\begin{array}{l}\text { Interview } \\
\text { designation }\end{array}$ & Years* & Role in Bank & Sector/s \\
\hline A1 & $5-9$ & Credit analyst & Telecommunications \\
A2 & $5-9$ & Credit analyst & Mining and mining services \\
SA3 & $20-24$ & Credit analyst & Government, education, telecommunications \\
SA4 & $20-24$ & Credit analyst & All sectors \\
SA5 & $20-24$ & Credit analyst & All sectors \\
SA6 & $20-24$ & Credit analyst & All sectors \\
SA7 & $25-29$ & Credit analyst & Financial services (ex-banks) and government \\
A8 & $<5$ & Risk advisor & Financial services (ex-banks) \\
A9 & $<5$ & Risk advisor & All sectors \\
A10 & $5-9$ & Risk advisor & All sectors \\
SA11 & $10-14$ & Risk advisor & All sectors \\
SA12 & $10-14$ & Risk advisor & All sectors \\
SA13 & $15-19$ & Risk advisor & All sectors \\
SA14 & $15-19$ & Risk advisor & Engineering and mining services \\
SA15 & $15-19$ & Risk advisor & All sectors \\
SA16 & $30-34$ & Risk advisor & Financial services (ex-banks) \\
& & & \\
* This denotes years in the workplace which is not the same as years in current role \\
\hline
\end{tabular}




\section{Appendix 1 Interview Guide}

\section{Background information}

- How long have you worked as an analyst and in what kind of roles?

- What companies or sectors do you mainly work with?

- What is your particular interest in or experience with derivatives?

\section{Interview questions}

1. To what extent do the disclosures in annual reports allow you to (a) evaluate the significance of derivatives to an entity’s financial position and performance, (b) understand the nature and extent of their risk, and (c) understand an entity’s practices and processes for managing that risk?

2. How do you think the disclosures could be improved, if at all? 